\title{
PENGGUNAAN SERAT BATANG POHON PISANG SEBAGAI BAHAN DASAR PEMBUATAN PAPAN SERAT TERHADAP MUTU PAPAN SERAT
}

\author{
Dini Akbar Juniardi , Dr. Gina Bachtiar, Prof. Dr. Amos Neolaka, M.Pd
}

\begin{abstract}
The purpose of this study was to determine and prove the existence of a banana trunk fibers influence the quality of fiber board and meet the requirements of the water content, density, development of thick, water absorption, strength of pull screw, determination bending modulus of elasticity, flexural modulus and fracture determination based on SNI 01 -4449-2006 fiberboard. Materials used are banana trunk fiber kepok and urea formaldehyde 13\%. Testing the hypothesis of water content obtained thitung $<T_{\text {Table }}$ so that $\mathrm{H}_{0}$ is accepted, with an average water content of $12.33 \%$ falls below the standard at $13 \%$ moisture content. Testing hypotheses derived density $t_{\text {hitung }} \geq T_{\text {Table }}$ so $H_{0}$ is rejected, with the average density of $0.61 \mathrm{gr} / \mathrm{cm}^{3}$ is above the standard density of 0.4 to $0.84 \mathrm{gr} / \mathrm{cm}^{3}$. Testing hypotheses derived heavy development $t_{\text {hitung }} \geq T_{\text {Table }}$ so $\mathrm{H}_{0}$ is rejected, with an average thickness development of $76.51 \%$ exceeds the development standard which is $12 \%$ thicker. Testing the hypothesis of water absorption obtained thitung $\geq$ $T_{\text {Table }}$ so $H_{0}$ is rejected, with an average water absorption of $156.97 \%$ over standard water absorption is 35\%. Constancy hypothesis testing screw pull obtained $t_{\text {hitung }} \leq T_{\text {Table }}$ that $H_{0}$ is accepted, with firmness screw pull $0.51 \mathrm{~kg} / \mathrm{cm}^{3}$ an average of falls below the standard determination of $20 \mathrm{~kg} / \mathrm{cm}^{3}$ remove the screws. Constancy hypothesis testing flexural modulus of fracture obtained thitung $\geq$ $T_{\text {Table }}$ so $\mathrm{H}_{0}$ is rejected, the flexural modulus determination fracture $82.22 \mathrm{~kg} / \mathrm{cm}^{3}$ average flexural modulus determination exceeds the standard at $51 \mathrm{~kg} / \mathrm{cm}^{3}$ broken. Constancy hypothesis testing flexural modulus of elasticity obtained thitung $\geq T_{\text {Table }}$ so $\mathrm{H}_{0}$ is rejected, the flexural modulus of elasticity firmness average $9704.3 \mathrm{~kg} / \mathrm{cm}^{3}$ exceeds standard determination of flexural modulus of elasticity of $8200 \mathrm{~kg} / \mathrm{cm}^{3}$. Testing the physical and mechanical properties of fiber board with the basic ingredients kepok banana trunk fiber refers to the standard SNI 01-44492006 fiberboard. The conclusion of this study is based fiberboard banana tree trunks fit for use in places that are not susceptible to water. Because not all physical and mechanical properties meet the requirements of SNI 01-4449-2006.
\end{abstract}




\section{PENDAHULUAN}

Pembangunan konstruksi yang sangat maju di Indonesia memberi dampak tertentu bagi ketersediaan bahan baku penunjang pembangunan di Indonesia. Salah satu bahan dasar yang mengalami tahap kritisnya adalah ketersediaan bahan dasar kayu. Penebangan kayu (pohon) secara besar-besaran menyebabkan berkurangnya ketersediaan kayu dari alam. Kayu dapat dimanfaatkan sebagai penunjang pembangunan konstruksi, selain itu kayu juga digunakan sebagai bahan dasar pembuat perabot atau properti pada rumah tinggal. Banyak tipe kayu yang digunakan untuk perabotan, lantai, dan konstruksi diambil dari hutan tropis di Afrika, Asia, dan Amerika Selatan (Sudjatmiko, 2005).

Batang pisang kepok memiliki kualitas serat yang lebih baik dibandingkan dengan jenis pisang yang lain. Menurut Aswanto(1989) dalam Tempo-online(1989), Tarikan lusi pada serat pisang kepok memerlukan tenaga $49 \mathrm{~kg}$, pada pisang kluthuk (batu) $47 \mathrm{~kg}$, dan pisang klijang $42 \mathrm{~kg}$. Sementara itu, tarikan pakan pada kain serat pisang kepok membutuhkan tenaga $23 \mathrm{~kg}$, serat kluthuk $18 \mathrm{~kg}$, dan klijang $30 \mathrm{~kg}$. Kekuatan serat pisang ini jauh lebih tinggi dibandingkan dengan kain dari benang kapas, yang hanya memberi tarikan lusi sebesar $26 \mathrm{~kg}$ dan pakan $18 \mathrm{~kg}$.

\section{METODA}

Dalam penelitian ini, batang pisang dijadikan sebagai bahan dasar yang diharapkan mampu menjadi pengganti serat kayu pada papan serat. Bahan dasar tersebut merupakan limbah yang berasal dari perkebunan dan dapat mencemari lingkungan jika tidak ada pengolahan lebih lanjut. Perekat urea formaldehida adalah jenis perekat yang didapat dari hasil reaksi antara urea dan formaldehida. Perekat urea formaldehida merupakan perekat yang umum digunakan dalam skala industri karena harganya yang lebih ekonomis dibanding dengan perekat jenis lain. Selain itu, urea formaldehida memiliki sifat pengerasan yang lebih cepat dibandingkan dengan perekat phenol formaldehida (Daud et al, 2009) . dalam pembuatan papan ini menggunakan perekat UF sebanyak $13 \%$ dari berat kering bahan baku. Beberapa alat yang digunakan adalah hot dan cold press dan beberapa alat pendukung lainnya. Pembuatan papan dilakukan dengan memberikan kempa panas $105^{\circ} \mathrm{C}$ selama 15 menit dengan beban kempa sebesar $23 \mathrm{~kg} / \mathrm{cm}^{3}$. Dengan sasaran kerapatan sebesar $0,7 \mathrm{gr} / \mathrm{cm}^{3}$. Dilakukan pengujian terhadap sifat fisik berupa kadar air, kerapatan, 
pengembangan tebal dan penyerapan air serta pengujian terhadap sifat mekanik berupa keteguhan cabut sekrup, keteguhan lentur modulus patah dan keteguhan lentur modulus elastisitas. Pengujian sifat fisik dan mekanik mengacu pada SNI 01-4449-2006 papan serat.

\section{HASIL DAN PEMBAHASAN}

Kadar air papan serat batang pohon pisang dengan perekat urea formaldehida $13 \%$ yang diuji menghasilkan nilai kadar air rata-rata 12,33\% lebih kecil dari nilai maksimum kadar air berdasarkan SNI 01-4449-2006 yaitu 13\%, sehingga nilai kadar air papan serat batang pohon pisang dengan perekat urea formaldehida 13\% memenuhi nilai kadar air SNI 01 4449-2006. Kerapatan papan serat batang pohon pisang dengan perekat urea formaldehida $13 \%$ yang diuji menghasilkan nilai kerapatan rata-rata $0,61 \mathrm{gr} / \mathrm{cm}^{3}$ lebih besar dari nilai minimum kerapatan berdasarkan SNI 01-4449-2006 yaitu 0,4 - 0,8 gr/ $/ \mathrm{cm}^{3}$, sehingga nilai kerapatan papan serat batang pohon pisang dengan perekat urea formaldehida 13\% memenuhi nilai kerapatan SNI 01-4449-2006. Pengembangan tebal papan serat batang pohon pisang dengan perekat urea formaldehida $13 \%$ yang diuji menghasilkan nilai pengembangan tebal rata-rata $76,51 \%$ lebih besar dari nilai maksimum pengembangan tebal berdasarkan SNI 01-4449-2006 yaitu 12\%, sehingga nilai pengembangan tebal papan serat batang pohon pisang dengan perekat urea formaldehida $13 \%$ tidak memenuhi nilai pengembangan tebal SNI 01-4449-2006. Penyerapan air papan serat batang pohon pisang dengan perekat urea formaldehida 13\% yang diuji menghasilkan nilai penyerapan air rata-rata $156,97 \%$ lebih besar dari nilai maksimum penyerapan air berdasarkan SNI 01-4449-2006 yaitu 35\%, sehingga nilai penyerapan air papan serat batang pohon pisang dengan perekat urea formaldehida $13 \%$ tidak memenuhi nilai penyerapan air SNI 01-4449-2006.

Keteguhan cabut sekrup papan serat batang pohon pisang dengan perekat urea formaldehida $13 \%$ yang diuji menghasilkan nilai keteguhan cabut sekrup rata-rata 0,51 $\mathrm{kg} / \mathrm{cm}^{2}$ lebih kecil dari nilai minimum keteguhan cabut sekrup berdasarkan SNI 01-44492006 yaitu $20 \mathrm{~kg} / \mathrm{cm}^{2}$, sehingga nilai keteguhan cabut sekrup papan serat batang pohon pisang dengan perekat urea formaldehida $13 \%$ tidak memenuhi nilai keteguhan cabut 
sekrup SNI 01-4449-2006. Keteguhan lentur modulus patah papan serat batang pohon pisang dengan perekat urea formaldehida $13 \%$ yang diuji menghasilkan nilai keteguhan lentur modulus patah rata-rata $82,22 \mathrm{~kg} / \mathrm{cm}^{2}$ lebih besar dari nilai minimum keteguhan lentur modulus patah berdasarkan SNI 01-4449-2006 yaitu $51 \mathrm{~kg} / \mathrm{cm}^{2}$, sehingga nilai keteguhan lentur modulus patah papan serat batang pohon pisang dengan perekat urea formaldehida 13\% memenuhi nilai keteguhan lentur modulus patah SNI 01-4449-2006. Keteguhan lentur modulus elastisitas papan serat batang pohon pisang dengan perekat urea formaldehida $13 \%$ yang diuji menghasilkan nilai keteguhan lentur modulus elastisitas rata-rata $9704,3 \mathrm{~kg} / \mathrm{cm}^{2}$ lebih besar dari nilai minimum keteguhan lentur modulus patah berdasarkan SNI 01-4449-2006 yaitu $8200 \mathrm{~kg} / \mathrm{cm}^{2}$, sehingga nilai keteguhan lentur modulus elastisitas papan serat batang pohon pisang dengan perekat urea formaldehida 13\% memenuhi nilai keteguhan lentur modulus elastisitas SNI 01-4449-2006.

Adanya perbedaan nilai yang cukup besar pada setiap papan yang di uji pada pengujian pengembangan tebal, penyerapan air, keteguhan lentur modulus patah dan elastisitas. Disebabkan dari proses pemberian perekat yang kurang merata dan sering terjadinya penggumpalan pada saat penyemprotan dengan sprayer. Karena, perekat mempengaruhi kualitas dari papan serat. Selain itu masih terdapatnya serat kasar pada beberapa papan juga mempengaruhi kualitas dari papan yang dihasilkan.

\section{KESIMPULAN}

Berdasarkan hasil penelitian yang dilaksanakan sesuai dengan ketentuan SNI 01-44492006, hasil yang dapat disimpulkan dari hipotesis yang telah diuji adalah sebagai berikut:

1. Sifat fisik papan serat batang pohon pisang berupa kerapatan dan kadar air memenuhi persyaratan papan serat SNI 01-4449-2006. Sehingga serat batang pohon pisang layak dijadikan sebagai bahan dasar pembuatan papan serat.

2. Sifat fisik papan serat batang pohon pisang berupa pengembangan tebal dan penyerapan air belum memenuhi standar papan serat SNI 01-4449-2006.

3. Sifat mekanik papan serat batang pohon pisang berupa keteguhan lentur modulus patah dan elastisitas memenuhi persyaratan SNI 01-4449-2006. Sehingga serat batang pohon pisang layak dijadikan sebagai bahan dasar pembuatan papan serat. 
4. Sifat mekanik papan serat batang pohon pisang berupa keteguhan cabut sekrup belum memenuhi persyaratan SNI 01-4449-2006.

5. Memiliki pengembangan tebal dan penyerapan air yang tinggi sehingga papan serat batang pohon pisang belum dapat digunakan pada tempat yang lembab.

6. Serat kering yang dibutuhkan untuk membuat satu buah papan berukuran $30 \times 30$ x $1 \mathrm{~cm}$ dengan kerapatan 0,7 gr/cm3 diperlukan 557,52 gr. Dengan kadar air sekitar $97 \%$, Batang pisang utuh yang diperlukan untuk membuat satu buah papan mencapai $18,584 \mathrm{~kg}$.

\section{DAFTAR PUSTAKA}

Anonim. 2010. Mengenal Bahan Perekat Kayu. http://gurumuda.com/bse/mengenal-bahanperekat-kayu [Martno, Budi, 2008, Teknik Perkayuan Jilid 1 untuk SMK oleh Budi Martono, Jakarta : Pusat perbukuan Departemen Pendidikan Nasional, h. 58 - 63. ]. [6 Maret 2011].

Bhutler, Rhett A. 2008. Indonesia : Profil Lingkungan. http://world.mongabay.com/indonesian/profil.html [6 Februari 2011]

Dalimartha, Setiawan. 2007. Atlas tumbuhan obat Indonesia. Jilid 3. Cetakan IV. penerbit : Puspaswara. Hal. 97. Jakarta.

(a) Daud et al. 2009. Pengaruh Rasio Perekat Urea Formaldehida (UF) dan Isosianat Terhadap Kadar Emisi Formaldehida Kayu Lapis Sengon (Paraserianthes falcataria). $\quad$ http://daudforesterunhas.blogspot.com/2009/09/pengaruh-rasioperekat-urea.html [29Desember 2010].

Lisnawati. 2000. Biologi serat abaka dan musa.sp lain berdasarkan sifat fisis kimia dan kelayakan untuk bahan baku pulp dan paper. Skripsi. FMIPA IPB. Bogor. Tidak dipublikasikan.

Macklin, Boy. 2009. Pemanfaatan limbah dari tanaman pisang. Online Buku. http://onlinebuku.com/2009/01/29/pemanfaatan-limbah-dari-tanaman-pisang/ [6 Maret 2011].

Muiz, Abdul. 2005. Pemanfaatan Batang Pisang (musa sp.) Sebagai Bahan Baku Papan Serat. Skripsi. Fakultas Kehutanan. IPB. Bogor. tidak dipublikasikan. 
Sigiro, Julius Zakson. 2010. Pengempaan dingin. Julius's Blog.

http://juliusthh07.blogspot.com/2010/03/pengempaan-dingin.html [2 Mei 2011].

SNI 2006.Papan Serat. SK SNI 01-4449-2006. Badan Standardisasi Nasional. Indonesia.

SNI 1998. Urea formaldehida cair untuk perekat papan partikel. SNI 06-4565-1998. Badan Standardisasi Nasional. Indonesia.

SNI 1998. Urea formaldehida carie untuk perekat kayu lapis. SNI 06-0060-1998. Badan Standarisasi Nasional. Indonesia.

Sholekhudin, M. 2007. Buah dibuang, batang jadi uang. Gedabrusan Sumbang Dibuwang Sayang. http://emshol.multiply.com/journal/item/278 [14 Maret 2011].

Sunarjono, H. 2005. Berkebun 21 Jenis Tanaman Buah. Penebar Swadaya. Jakarta.

Tempo Online. 1989. Eksklusif Dengan Serat Pisang. http://majalah.tempointeraktif.com/id/arsip/1989/12/09/LT/mbm.19891209.ILT2154 3.id.html [ 13 Maret 2011].

Wido Cepaka Warih. 2009. Mencegah penebangan hutan secara liar melalui pendekatan neo humanisme. Lingkungan hidup (opini). http://www.anakui.com/2009/11/06/mencegah-penebangan-hutan-secara-liarmelalui-pendekatan-neo-humanisme/ [14 Maret 2011].

Wikipedia. 2010. Urea. http://id.wikipedia.org/wiki/Urea - [8:41pm-20 Januari 2011].

Wikipedia. 2010. Formaldehida. http://id.wikipedia.org/wiki/Formaldehida [8:36 - 20 Januari 2011]. 